\title{
Genetic Diversity of the Structure of HSP70 Gene in Kampung Unggul Balitbangtan (KUB), Walik, and Kate Walik Chickens
}

\author{
A. Aryani ${ }^{a}$, D. D. Solihinn ${ }^{\mathrm{b}, *}$, C. Sumantric ${ }^{c}$, R. Afnanc, \& T. Sartika ${ }^{\mathrm{d}}$ \\ ${ }^{a}$ Department of Biology Education, Faculty of Mathematics and Natural Science Education, \\ Indonesia University of Education, \\ Jalan Dr. Setiabudi No. 229 Bandung 40154, Indonesia \\ ${ }^{b}$ Department of Biology, Faculty of Mathematics and Natural Sciences, IPB University (Bogor Agricultural University) \\ 'Department of Animal Production and Technology, Faculty of Animal Science, \\ IPB University (Bogor Agricultural University) \\ Jalan Agatis, Kampus IPB Darmaga Bogor 16680, Indonesia \\ dIndonesian Research Institute for Animal Production \\ Jalan Veteran III, PO. BOX 221 Ciawi Bogor 16002, Indonesia \\ *Corresponding author: dduryadi@yahoo.com \\ (Received 15-05-2018; Revised 05-04-2019; Accepted 25-04-2019)
}

\begin{abstract}
Our research was designed to identify the sequence variations of heat shock protein 70 (HSP70) gene in three breeds of native Indonesian chickens, Kampung Unggul Balitbangtan (KUB) chicken, Walik chicken, and Kate Walik chicken. Total DNA was isolated from the whole blood using a DNeasy blood and tissue kit. The HSP70 gene was amplified and sequenced from 94 chickens using PCR. The amplification product was $787 \mathrm{bp}$ long, consisting of a $210 \mathrm{bp}$ promoter region, a $112 \mathrm{bp}$ long 5 'untranslated region (UTR), and a 465 bp protein coding region. Our KUB, Walik, and Kate Walik chicken HSP70 gene sequence alignments express genetic diversity in the promoter region (insertions and deletions), 5'UTR (deletions and nucleotide substitutions), and at the beginning of the coding region (nucleotide substitutions). Four haplotypes, H1, H2, H3, and H4, were identified in the HSP70 gene protein coding region. The haplotype $\mathrm{H} 2$ was found in all three chickens, while $\mathrm{H} 4$ was only found in Walik chicken. The $\mathrm{H} 4$ is a novel haplotype which never reported before. Based on a medianjoining network analysis, $\mathrm{H} 4$ is a haplotype produced by mutations at two specific sites (g.370A>G and $\mathrm{g} .388 \mathrm{C}>\mathrm{G}$ ) in the protein coding region of the HSP70 gene of the chicken. It could be concluded that Walik chicken can be used as a standard for heat stress genotyping in Indonesian local chickens, because it has complete HSP70 gene haplotypes.
\end{abstract}

Keywords: HSP70 gene; Indonesian native chicken; polymorphism; haplotype; PCR-Sequencing

\section{INTRODUCTION}

Indonesia has a high diversity of local chicken breeds, which have the potential to be developed as a national food security source, but their utilizations are not optimal. So far, 31 breeds of local chickens have been identified (Nataamijaya, 2010). Indonesian local chickens, aside from being kept as broilers and egg-laying hens, are also kept as domestic companions, serving as yard decorators, the source of neighborly complaints, and the provider of ritual needs, or merely to provide gratification through melodious voices (Sartika et al., 2016). One of Indonesia's local chickens is the Walik chicken having curly body feathers (frizzle). Adult Walik chickens are quite resistant to weather changes. However, Walik chickens have a rather limited population, existing only in certain regions, and are, therefore, rare local chickens that need to be further explored (Sartika et al., 2016). In addition to local chickens, Kampung Unggul Balitbangtan (KUB) chickens, which are the result of six generations of selection using female chickens from Cianjur, Depok, Majalengka, and Bogor regions, have several advantages. These include the high egg production and the majority do not brood (Minister of Agriculture Decree No. 274/Kpts/SR.120/2/2014).

Poultry does not have sweat glands, and almost all of the poultry body is covered by feathers. Therefore, dissipation of body heat to the environment is difficult, and poultry is quite susceptible to heat stress (Tamzil, 2014). High environmental temperature has negative impacts on physiological conditions (metabolic and hormonal activity, and body temperature control) and chicken productivity. Heat stress is a primary poultry problem worldwide, especially in broiler and egg-laying chickens. Heat stress can occur anytime when ambient temperature exceeds the limit of comfort zone $\left(>28^{\circ} \mathrm{C}\right)$. Heat stress in chickens can cause growth disruption, decreased egg quality, and death.

Heat shock protein 70 (HSP70), among others, is produced by organisms to overcome heat stress. The HSP70 gene works as a chaperone, the duty of which is to regulate the refolding of proteins properly, to 
help protect cells from damage caused by heat stress (Tkáčová \& Angelovičová, 2012). The HSP70 gene in chicken, Gallus gallus, is located in the fifth chromosome and consists of only one exon with a coding-region length of 1,905 bp (Morimoto et al., 1986). The complete sequence of the chicken HSP70 gene is available in GenBank (J02579). Research on the polymorphisms of HSP70 gene between breeds of chickens has progressed based on the sequence of HSP70 gene of chickens. One such study identified polymorphisms in the coding region of the HSP70 genes in broiler chickens of different breeds at positions g.370A $>\mathrm{G}$ (identical to g.258A $>\mathrm{G}$ from the start codon) and g.388C $>\mathrm{G}$ (identical to g.276C $>\mathrm{G}$ from the start codon). Three of the detected alleles (hsp70-1, hsp70-2, and hsp70-3) were associated with the nature of resistance to heat stress, and therefore, it's potential to be used as a candidate gene for heat stress (Mazzi et al., 2003). The results of this study have encouraged additional research in the other chickens: Indonesian local chicken (Tamzil et al., 2013a), Taiwanese local chicken (Liang et al., 2016), and Thailand local chicken (Duangjinda et al., 2017).

The purpose of this study was to obtain data on the diversity of HSP70 genes in Indonesian local chickens: KUB, Walik, and Kate Walik chickens. We identified the genetic variability of the chicken HSP70 gene promoter, 5'UTR, and coding region. These data are essential, both as an informational database, especially in response to a high environmental temperature during summer, and as a basis for the development of heat-resistant chicken strains. In this study, we used two different feather structures. KUB chicken has a normal feather, but Walik chicken and Kate Walik chicken have frizzle feathers. The frizzle (F) is an autosomal and incompletely dominant gene, which has a nonframeshift deletion in KRT75 ( $\mathrm{Ng}$ et al. 2012). The $\mathrm{F}$ gene may reduce the heat insulation of feathers by curling and reducing their sizes. Many reports have proved that frizzle $(\mathrm{F})$ and naked neck $(\mathrm{Na})$ are well known as major marker genes affecting heat stress tolerance, resistant to diseases, and better immune system (Fathi et al. 2013, 2014). Several tropical countries have introduced these genes in breeding programs to improve performance and adaptability of chickens to hot ambient temperatures (Fathi et al. 2013, 2014; Carabańo et al. 2019). Recently, supplementation of vitamin and mineral are used as antioxidants to reduce the negative effects of heat stress (Rayani et al. 2017; Mohamed et al. 2019).

\section{MATERIALS AND METHODS}

\section{Sample Collection and DNA Isolation}

In this study, we used 94 chickens from three breeds of native Indonesian chickens: KUB, Walik, and Kate Walik chickens (Table 1). Specifically, the KUB chicken sampling fulfilled the requirements of the Balitbangtan ethics code, registration number Balitbangtan/Balitnak/A/01/2018 in 2018. Chicken DNA material comes from the whole blood taken from the wing vein $( \pm 0.5-1.0 \mathrm{~mL})$. Genome DNA extraction and purification were carried out using a DNeasy blood and tissue kit based on the spin column procedure (Qiagen, Venlo, Netherlands).

\section{Amplification and Sequencing}

DNA amplification was performed using the polymerase chain reaction (PCR) with a primary pair of forward, 5'-CGATCTGGCTGCAATCTACG-3' (Gan et al., 2015) and reverse, 5'-CTGGGAGTCGTTGAAGT AAGCG-3' (Mazzi et al., 2003) primers based on the chicken HSP70 gene (Morimoto et al., 1986). The amplified PCR target product is $787 \mathrm{bp}$ long, consisting of a $210 \mathrm{bp}$ promoter region, a $112 \mathrm{bp} 5^{\prime}$ untranslated region (UTR), and a $465 \mathrm{bp}$ coding region (Figure 1). The PCR mixture consisted of $12.5 \mu \mathrm{L}$ of GoTaq Green Master Mix (Promega, Madison, Wisconsin) containing 2x GoTaq Green reaction buffer, $400 \mu \mathrm{M}$ of each of four deoxynucleoside triphosphates, and

Table 1. Number of chicken samples analyzed

\begin{tabular}{lccccc}
\hline \multicolumn{1}{c}{ Breed } & $\mathrm{n}$ & Male & Female & Management system & Source \\
\hline Kampung Unggul & 50 & 20 & 30 & Intensive (battery cage) & Indonesian Research Institute for Animal \\
Balitbangtan (KUB) & & & & Semi Intensive & Production, Bogor \\
Walik & 41 & 4 & 37 & Semi Intensive & Private collection \\
Kate Walik & 3 & 1 & 2 & collection & Private \\
\hline
\end{tabular}

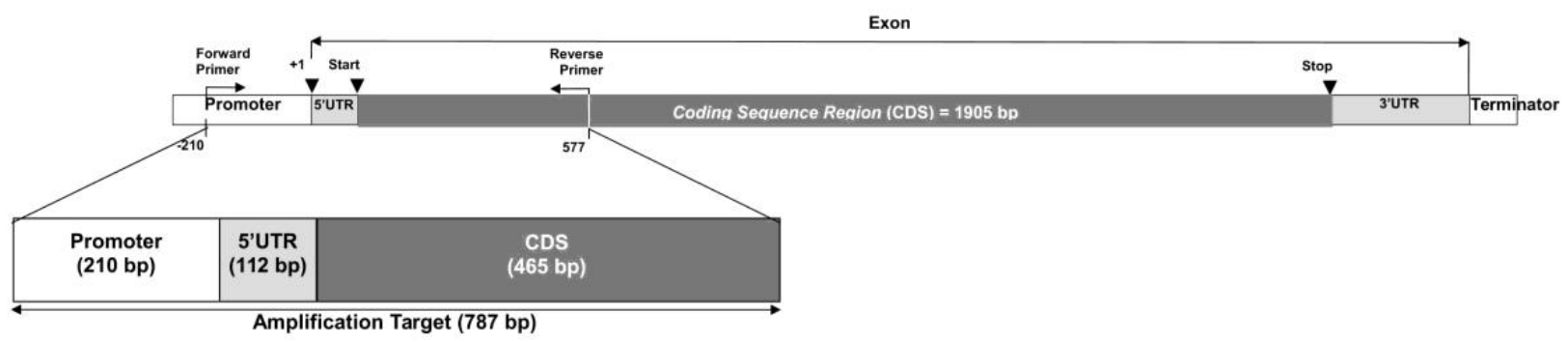

Figure 1. Amplification target of the HSP70 gene in chicken (J02579) as a reference. The arrow shows the attachment of the primer: the forward primer attaches at position -210 (promoter region), and the reverse primer attaches at position +577 (protein coding region) of the HSP70 gene of chicken. 
$3 \mathrm{mM} \mathrm{MgCl}, 1 \mu \mathrm{L}$ of each primer HSP70 forward and HSP70 reverse $(10 \mu \mathrm{M}), 1 \mathrm{uL}$ DNA template (100 ng), and nuclease-free water to final volume of $25 \mu \mathrm{L}$. The PCR program consisted of an initial denaturing at $95^{\circ} \mathrm{C}$ for 5 minutes, followed by 35 cycles of denaturation at $95^{\circ} \mathrm{C}$ for 30 seconds, annealing at $58^{\circ} \mathrm{C}$ for 45 seconds, and elongation at $72^{\circ} \mathrm{C}$ for 1 minute. The amplification process was terminated by extension at $72^{\circ} \mathrm{C}$ for 5 minutes. PCR products were analyzed by electrophoresis on an agarose gel, stained with ethidium bromide, and then sequenced with ABI@ PRISM bigdye terminator cycle sequencing kit v3.1 by First BASE Laboratories (Selangor, Malaysia).

\section{Data Analysis}

Chromatogram nucleotide sequencing results, both forward and reverse, were edited using Bioedit (Hall, 2011). The edited nucleotides were then aligned with the reference chicken HSP70 gene from National Center for Biotechnology Information (NCBI) GenBank using Clustal W implemented in Molecular Evolutionary Genetic Analysis (MEGA) version 6 software (Tamura et al., 2013). Similarity searching with our HSP70 gene coding sequences was performed with the Basic Local Alignment Search Tool-nucleotide application (BLASTn) at NCBI. Reconstruction of haplotype networks was made to explore further evolutionary relationships between nucleotide substitutions using Population Analysis with Reticulate Trees (PopART) software (Leigh \& Bryant, 2015). Analysis of potential CpG island in the chicken HSP70 gene was detected by MethPrimer (http://www.urogene.org/methprimer).

\section{RESULTS}

\section{Amplification of the Chicken HSP70 Gene}

Partial amplification of HSP70 gene in KUB, Walik, and Kate Walik chickens produced 787 bp DNA fragments, as expected (Figure 2). The sequenced DNA fragments, after being aligned with the reference chicken HSP70 gene, were found to consist of a $210 \mathrm{bp}$ promoter region, a 112 bp 5'UTR, and a 465 bp coding region.

\section{Analysis of the Chicken HSP70 Gene}

Promoter Region. The results of sequencing analysis showed that nucleotide variations were found at posi- tions $-103,-99,-11,-6$, and -5 in the promoter region of the KUB, Walik, and Kate Walik chicken HSP70 genes compared to reference chicken (Table 2). However, the KUB, Walik, and Kate Walik chickens had identical nucleotide sequences of promoter region of HSP70 gene. Two deletions and three insertions were found in the KUB, Walik, and Kate Walik chicken HSP70 gene partial promoter region sequence alignment, regarding to chicken HSP70 gene (Figure 3). The deletions indicated the loss of a guanine $(\mathrm{G})$ base at position -103 , and the loss of a cytosine (C) base at location -99 . In addition to these deletions, there were the insertions of two $G$ bases at positions -11 and -6 , and the inclusion of one $C$ base at position -5 .

The promoter region of chicken HSP70 gene showed consensus-motif sequences consisted of a TATA box, Heat Shock Elements 1 and 2 (HSE 1 and HSE 2), Specificity Protein 1 (SP 1), and CAAT box (Figure 3). The primary recognition element in the promoter region of the chicken HSP70 gene was a TATA box consisted of the sequence 5'-TATAAA-3', found at position -24 through -19 . Another recognition element in the promoter region of chicken HSP70 gene was HSE, consisted of HSE 1 with a sequence of 5'-CTGGCAGGTTCCAG-3', and the HSE 2 with a sequence of 5'-CCTTAGCGTTCTGGC-3'. The two heat shock elements overlapped at positions -55 through -42 in HSE 1 and at locations -65 through -51 in HSE 2. The other recognition elements found in the promoter region of chicken HSP70 gene was SP 1 (a type of GC box), with the sequence of 5'-GGGCGG-3', located at position -135 through -130 . There were two CAAT box elements with complementary nucleotide sequences of 5'-ATTG-3' found at location -152 through -149 , and -71 through -68 .

5'UTR. Our sequencing and alignment of the 5'UTR of HSP70 gene in KUB, Walik, and Kate Walik chickens

Table 2. Nucleotide variation in the promoter region of the HSP70 gene in Kampung Unggul Balitbangtan (KUB), Walik, and Kate Walik chickens with respect to the chicken reference sequence

\begin{tabular}{lcccccc}
\hline \multirow{2}{*}{ Breed code } & n & \multicolumn{5}{c}{ Nucleotide position } \\
\cline { 3 - 7 } & & -103 & -99 & -11 & -6 & -5 \\
\hline Ref. chicken & 1 & G & C & - & - & - \\
KUB & 50 & - & - & G & G & C \\
Walik & 41 & - & - & G & G & C \\
Kate Walik & 3 & - & - & G & G & C \\
\hline
\end{tabular}

Figure 2. Visualization of the HSP70 gene PCR products in KUB chicken (a) and Walik chicken (b). $M=1 \mathrm{~Kb}$ of DNA Ladder, 1-6= PCR product. 
with reference to chicken HSP70 gene sequence showed two deletions and one transition (Figure 4). Two A bases were deleted, one at position +32 and the other at +97 . Aside from these deletions, one transition $A$ to $\mathrm{G}$ was found at location +44 . These nucleotide variations, found at positions $+32,+44$, and +97 in the 5'UTR, produced two haplotypes (Table 3 ). The first haplotype was found in KUB ( $n=48)$, Walik $(n=38)$, and Kate Walik chickens $(n=3)$, while the second haplotype was only found in KUB $(n=2)$ and Walik chickens $(n=3)$. One of these specific nucleotide substitutions in the $5^{\prime} \mathrm{UTR}$ (g.44A>G) was only found in two KUB chickens and three Walik chickens.

Protein coding region. Four mutations could be seen in our coding region alignment (465 bp) at positions +370 , +388 , +533 , and +537 . The four mutations consisted of one transition and three transversions (Table 4). The transition occurred at position g.370A $>\mathrm{G}$ (identical to position g.258A $>\mathrm{G}$ from the start codon). The three transversions occurred at positions g.388C $>\mathrm{G}$ (identical to position g. $276 \mathrm{C}>\mathrm{G}$ from the start codon), g.533G $>\mathrm{C}$ (identical to position $\mathrm{g} .421 \mathrm{G}>\mathrm{C}$ from the start codon), and g.537C $>\mathrm{A}$ (identical to position g.425C $>\mathrm{A}$ from the start codon).

Based on the two mutations (g.370A $>\mathrm{G}$ and g.388C $>$ G) found in the HSP70 coding region of KUB, Walik, and Kate Walik chickens, four haplotypes were proposed (Figure 5). We named the four haplotypes Haplotype 1 (H1), Haplotype 2 (H2), Haplotype 3 (H3), and Haplotype $4(\mathrm{H} 4)$. All four haplotypes were occurred in Walik chickens. KUB chickens had three of the haplotypes (H1, H2, and H3), while Kate Walik chickens only had one haplotype $(\mathrm{H} 2)$. $\mathrm{H} 2$ was the most common haplotype and was found in KUB $(n=27)$, Walik $(n=22)$, and Kate Walik chickens $(n=3)$. H1 was found in $\operatorname{KUB}(n=7)$ and Walik chickens $(n=12)$, while H3 was also found in KUB $(n=16)$ and Walik chickens $(n=3)$.

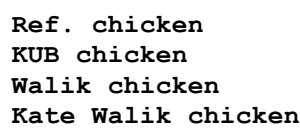

Ref. chicken KUB chicken Walik chicken Kate Walik chicken

Ref. chicken KUB chicken Walik chicken Kate Walik chicken

Ref. chicken KUB chicken Walik chicken Kate Walik chicken

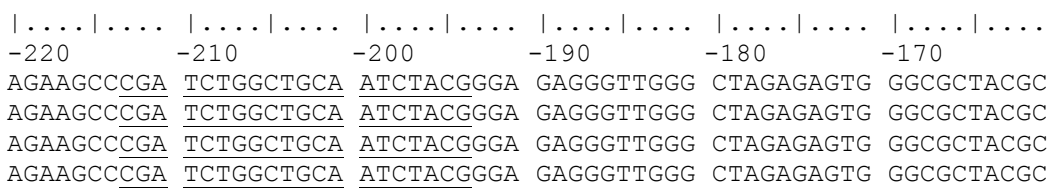

Forward Primer

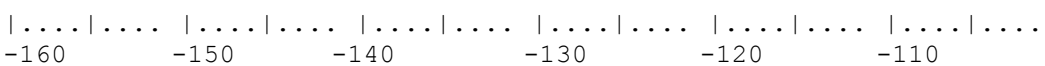

TTCTGATTGG GCAGGAGGCA AGGGGCGgGC GCTCTTCGGC TAGTCCGGGA GGCGGATTCG TTCTGATTGG GCAGGAGGCA AGGGGCGGGC GCTCTTCGGC TAGTCCGGGA GGCG-ATT-G TTCTGATTGG GCAGGAGGCA AGGGGCGGGC GCTCTTCGGC TAGTCCGGGA GGCG-ATT-G TTCTGATTGG GCAGGAGGCA AGGGGCGGGC GCTCTTCGGC TAGTCCGGGA GGCG-ATT-G CAAT SP 1

$|\ldots| \ldots|\ldots| \ldots|\ldots| \ldots|\ldots| \ldots|\ldots| \ldots|\ldots| \ldots|\ldots| \ldots|\ldots| \ldots \mid \ldots$

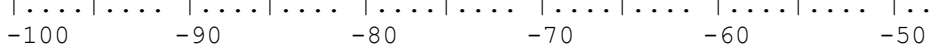
GTCAACTGCG GCAGTCGGGT GTCTGGATTG GTCCTTAgCG TTCTGGCAgG TTCCAGAAGA GTCAACTGCG GCAGTCGGGT GTCTGGATTG GTCCTTAGCG TTCTGGCAGG TTCCAGAAGA GTCAACTGCG GCAGTCGGGT GTCTGGATTG GTCCTTAgCG TTCTGGCAgG TTCCAGAAGA GTCAACTGCG GCAGTCGgGT GTCTGGATTG GTCCTTAgCG TTCTGGCAgG TTCCAGAAGA CAAT HSE 2 / HSE 1

$|\ldots| \ldots|\ldots| \ldots|\ldots| \ldots|\ldots| \ldots|\ldots| \ldots|\ldots|$

AGGCTAAGCG GACTATAAAG AGGGCGCGA- CGGC--CGTA

AGGCTAAGCG GACTATAAAG AGGGCGCGAG CGGCGCCGTA

AGGCTAAGCG GACTATAAAG AGGGCGCGAG CGGCGCCGTA

AGGCTAAGCG GACTATAAAG AGGGCGCGAG CGGCGCCGTA

TATA BOX

Figure 3. Promoter region sequences of the HSP70 gene in Kampung Unggul Balitbangtan (KUB), Walik, and Kate Walik chickens aligned to the chicken reference sequence. Underlined: forward primer site; bold: consensus motif sequences of CAAT, SP 1, HSEs, and a TATA box (Morimoto et al., 1986); hyphens: nucleotide base deletions.
Ref. chicken
Haplotype 1

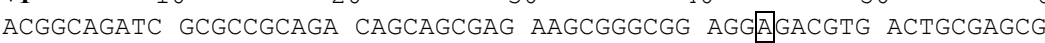 Haplotype 2

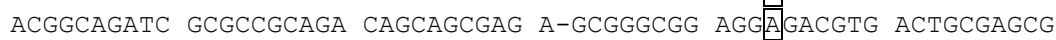 ACGgCAgAtC GCGCCGCAgA CAgCAgCGAg A-GCGgGCGg AgGGGACGTg ACTGCGAgCG

+1 $\left.^{\text {mRNA }} \cdots\right|_{10}$

$\ldots|\ldots|$

$\cdots|\cdots|$

$\ldots+\ldots \mid$

Ref. chicken Haplotype 1 Haplotype 2

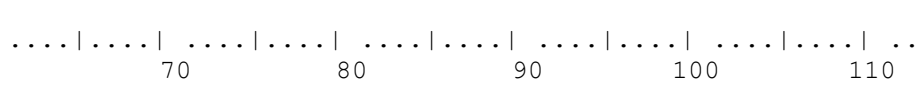

AgCAAgtgaC tgGCGgAgCg AgtggCtgaC TGACCAAgAg GAATCtAtCA TC

AGCAAGTGAC TGGCGGAGCG AgTGGCTGAC TGACCA-GAg GAATCTATCA TC

AgCAAgtgAC TGgCGgAgCG AgtgGCtgAC TGACCA-GAg GAATCTATCA TC

Figure 4. Alignment of two haplotypes in 5'UTR of the HSP70 gene in Kampung Unggul Balitbangtan (KUB), Walik, and Kate Walik chickens with the chicken reference sequence. Hyphens: nucleotide base deletions; in box: transversion. 
Conversely, H4 was only found in Walik chickens (n= 4).

We found that the wild haplotype of HSP70 gene in KUB and Walik chickens was H1, based on our HSP70 haplotype reconstruction using an Median-Joining network (Figure 6). The mutation at position g.388C $>\mathrm{G}$ produced $\mathrm{H} 2$, while the mutation at position g.370A>G produced H3. The new haplotype, H4, was only found in Walik chickens $(n=4)$, produced by the mutations at two specific coding regions at positions g.370A $>\mathrm{G}$ and g.388C $>\mathrm{G}$ of the chicken HSP70 gene.

CpG island. The existence of $\mathrm{CpG}$ island could be identified by using MethPrimer. The CpG island was mostly found in the promoter and the first parts of exon in several genes, especially in the housekeeping gene. Only one CpG island with $33 \mathrm{CpG}$ sites was found in the HSP70 gene promoter and exon of KUB, Walik, and Kate Walik chickens (Figure 7). CpG island had 376 bp long, and $61.7 \%$ of $\mathrm{G}+\mathrm{C}$ (Table 5$)$.

\section{DISCUSSION}

The promoter region of chicken HSP70 gene is upstream (5'-flanking) of the protein coding sequence and controls the regulation of the transcription process through the binding to various transcription factors that recognize specific DNA motif, i.e. TATA box, HSE, and SP 1 (Morimoto et al., 1986; Mazzi et al., 2003). The TATA box (Goldberg-Hogness box) is generally located around 30 nucleotides upstream of the initiation of transcription within the promoter region in eukaryotic cells, and plays a role in directing RNA polymerase II during transcription. HSE is a specific DNA sequence responsible for the activation of HSP70 gene transcription (Pelham, 1982). HSE elements are binding sites for heat shock [transcription] factors (HSFs) (Pelham, 1982).

The HSP70 gene is considered as an ideal biological marker for heat stress in livestock (Archana et al., 2017). The induction of HSP70 gene expression occurs when stress induces and activates transcription factors, such HSF, to bind to HSE. The binding of HSF to HSE allows the transcription of the HSP70 gene by RNA polymerase II (Akerfelt et al., 2010). Vertebrates have four transcription factors for heat shock gene i.e., HSF1, HSF2, HSF3, and HSF4. Aves have three HSFs, with HSF1 and HSF2 being homologous to transcription factors counterparts

Table 3. Haplotypes and nucleotide site variation in the $5^{\prime} \mathrm{UTR}$ of HSP70 gene in Kampung Unggul Balitbangtan (KUB), Walik, and Kate Walik chickens aligned to the chicken reference sequence

\begin{tabular}{|c|c|c|c|c|c|}
\hline \multirow{2}{*}{ Breed } & \multirow{2}{*}{$\mathrm{n}$} & \multicolumn{3}{|c|}{ Nucleotide position } & \multirow{2}{*}{ Haplotype } \\
\hline & & +32 & +44 & +97 & \\
\hline Ref. chicken & 1 & A & A & A & - \\
\hline \multirow[t]{2}{*}{ KUB } & 48 & - & $\mathrm{A}$ & - & 1 \\
\hline & 2 & - & G & - & 2 \\
\hline \multirow[t]{2}{*}{ Walik } & 38 & - & A & - & 1 \\
\hline & 3 & - & G & - & 2 \\
\hline Kate Walik & 3 & - & A & - & 1 \\
\hline
\end{tabular}

in mammals, whereas HSF3 is a specific transcription factor to aves (Fujimoto \& Nakai, 2010). The expression of chicken HSF3 transcription factor is nearly stable throughout the development of various tissues in chicken. HSF2 and HSF4 are present in normal, unstressed cells, playing key roles in response to various biological processes, including immune activation and cell differentiation (Akerfelt et al., 2010). Therefore, HSF1 and HSF3 are likely involved in heat stress response.

In the present study, the analysis of the HSP70 gene in KUB, Walik, and Kate Walik chickens showed the heterogeneity in the promoter region. Nucleotide variations found in the promoter region of the HSP70 gene are caused by the insertions and deletions of nucleotides at positions $-103,-99,-11,-6$, and -5 that are also found in broiler and naked neck chickens (Mazzi et al., 2003).

The analysis of the 5'UTR of HSP70 gene in KUB, Walik, and Kate Walik chickens detected nucleotide variations occurred at positions $+32,+44$, and +97 . One specific nucleotide substitution in the $5^{\prime} \mathrm{UTR}$ (g.44A>G) is only found in two KUB chickens and three Walik Chickens (Table 3). When combined with the specific nucleotide substitutions in the protein coding region, these nucleotide substitutions are included in our Haplotype 1 (H1).

Research on the genetic effect of nucleotide substitution in g.69A>G, SNP (single nucleotide polymorphism) in the 5 -flanking region and its association with thermotolerance trait show that only one genotype (GG) proved useful as a marker of heat stress resistance in local Chinese chickens (Gan et al., 2015; Chen et al., 2016). The nucleotide g.69A $>\mathrm{G}$ transition reported by Gan et al. (2015) and Chen et al. (2016) is identical to the position of g.44A>G transition in the 5' UTR of the HSP70 gene of chicken (Morimoto et al., 1986). It is because the number reported by Gan et al. (2015) and Chen et al. (2016) is based on translational start and the number reported by Morimoto et al. (1986) is based on transcriptional start.

A 5'UTR is upstream of the protein-coding sequence in many proteins and is important in regulating gene expression (Araujo et al., 2012; Leppek et al. 2018). Several polymorphisms have been reported in the $5^{\prime} \mathrm{UTR}$ of the bovine HSP70 $\left(\mathrm{bHSP}_{70}\right)$ gene in Pasundan cattle. Only two of these SNPs, g.1117G $>$ A and g.1125A $>C$,

Table 4. Haplotypes and mutations in the HSP70 gene protein coding region of Kampung Unggul Balitbangtan (KUB), Walik, and Kate Walik chickens compared with the chicken reference sequence

\begin{tabular}{|c|c|c|c|c|c|c|}
\hline \multirow{2}{*}{ Breed } & \multirow{2}{*}{$\mathrm{N}$} & \multicolumn{4}{|c|}{ Nucleotide position } & \multirow{2}{*}{ Haplotype } \\
\hline & & +370 & +388 & +533 & +537 & \\
\hline Ref. chicken & 1 & A & $\mathrm{C}$ & G & $\mathrm{C}$ & - \\
\hline \multirow[t]{3}{*}{ KUB } & 7 & A & $\mathrm{C}$ & $\mathrm{C}$ & A & 1 \\
\hline & 27 & A & G & $\mathrm{C}$ & A & 2 \\
\hline & 16 & G & $\mathrm{C}$ & $\mathrm{C}$ & A & 3 \\
\hline \multirow[t]{4}{*}{ Walik } & 12 & A & $\mathrm{C}$ & $\mathrm{C}$ & A & 1 \\
\hline & 22 & A & G & $\mathrm{C}$ & A & 2 \\
\hline & 3 & G & $\mathrm{C}$ & $\mathrm{C}$ & A & 3 \\
\hline & 4 & G & G & $\mathrm{C}$ & $\mathrm{A}$ & 4 \\
\hline Kate Walik & 3 & A & G & $\mathrm{C}$ & A & 2 \\
\hline
\end{tabular}


Ref. chicken

Haplotype 1 Haplotype 2 Haplotype 3 Haplotype 4

Ref. chicken Haplotype 1 Haplotype 2 Haplotype 3 Haplotype 4

Ref. chicken Haplotype 1 Haplotype 2 Haplotype 3 Haplotype 4

Ref. chicken Haplotype 1

Haplotype 2 Haplotype 3 Haplotype 4

Ref. chicken Haplotype 1 Haplotype 2 Haplotype 3 Haplotype 4

Ref. chicken Haplotype 1 Haplotype 2 Haplotype 3

Haplotype 4

Ref. chicken Haplotype 1 Haplotype 2 Haplotype 3

Haplotype 4

Ref. chicken Haplotype 1 Haplotype 2

Haplotype 3 Haplotype 4

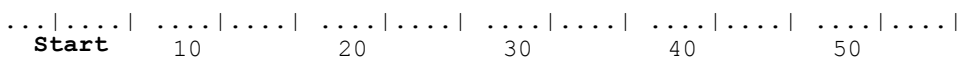

ATGTCTGGCA AAGGGCCGGC CATCGGCATC GATCTGGGCA CCACGTATTC TTGCGTGGGT ATGTCTGGCA AAGGGCCGGC CATCGGCATC GATCTGGGCA CCACGTATTC TTGCGTGGGT ATGTCTGGCA AAGGGCCGGC CATCGGCATC GATCTGGGCA CCACGTATTC TTGCGTGGGT

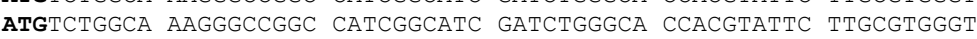
ATGTCTGGCA AAGGGCCGGC CATCGGCATC GATCTGGGCA CCACGTATTC TTGCGTGGGT $\left.\left.\left.\left.\left.\cdots|\cdots|\right|_{70} \cdots|\cdots|\right|_{80} \cdots|\cdots|\right|_{90} \cdots|\cdots|\right|_{100} \cdots|\cdots|\right|_{10} \cdots|\cdots|$ 120

GTCTTCCAGC ATGGCAAAGT GGAGATCATT GCCAACGACC AGGGGAACCG CACCACACCC GTCTTCCAGC ATGGCAAAGT GGAGATCATT GCCAACGACC AGGGGAACCG CACCACACCC GTCTTCCAGC ATGGCAAAGT GGAGATCATT GCCAACGACC AGGGGAACCG CACCACACCC GTCTTCCAGC ATGGCAAAGT GGAGATCATT GCCAACGACC AGGGGAACCG CACCACACCC GTCTTCCAGC ATGGCAAAGT GGAGATCATT GCCAACGACC AGGGGAACCG CACCACACCC

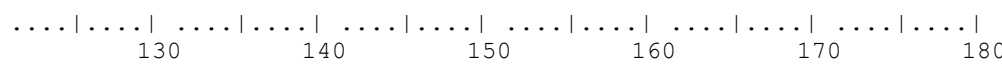

AGCTATGTGG CCTTCACCGA TACAGAGCGC CTCATCGGGG ATGCTGCCAA GAACCAAGTG AgCtATGTGG CCTTCACCGA TACAGAgCGC CTCATCGGGG ATGCTGCCAA GAACCAAGTG AGCTATGTGG CCTTCACCGA TACAGAGCGC CTCATCGGGG ATGCTGCCAA GAACCAAGTG AgCtAtgtgG CCTtCACCGA tACAgAgCGC CtCAtCGgGg AtgCtGCCAA GAACCAAGTG AgCtAtgtgG CCTTCACCGA tACAgAgCGC CTCATCGgGg ATGCTGCCAA GAACCAAGTG

$\ldots|\ldots| \ldots|\ldots| \ldots|\ldots| \ldots|\ldots| \ldots|\ldots| \ldots|\ldots| \ldots|\ldots| \ldots \mid$
GCAATGAACC CCACCAACAC CATCTTTGAT GCCAAGCGTC TCATCGGCCG CAAGTATGAT GCAATGAACC CCACCAACAC CATCTTTGAT GCCAAGCGTC TCATCGGCCG CAAGTATGAT GCAATGAACC CCACCAACAC CATCTTTGAT GCCAAGCGTC TCATCGGCCG CAAGTATGAT GCAATGAACC CCACCAACAC CATCTTTGAT GCCAAGCGTC TCATCGGCCG CAAGTATGAT GCAATGAACC CCACCAACAC CATCTTTGAT GCCAAGCGTC TCATCGGCCG CAAGTATGAT

$\ldots|\ldots| \ldots|\ldots| \ldots|\ldots| \ldots|\ldots| \ldots|\ldots| \ldots|\ldots| \ldots|\ldots| \ldots \mid$

GACCCCACAG TGCAGTCAGA CATGAAGCAC TGGCCCTTCC GTGTGGTGAA CGAGGGTGGC

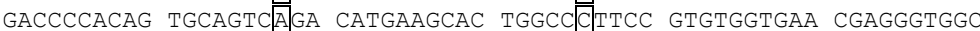
GACCCCACA TGCAGTCA GA CATGAaGCAC TGGCCGTTCC GTGTGGTGA CGAGGGTGGC GACCCCACAg TGCAGTCGA CATGAAGCAC TGGCCCTTCC GTGTGGTGA CGAGGGTGGC GACCCCACAg TGCAGTCG CATGAagCAC TGGCCGTTCC GTGTGGTGA CGAGGGTGGC

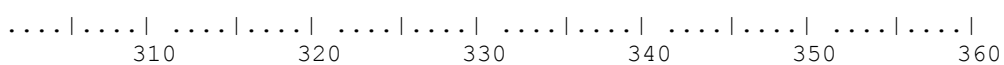

AAGCCCAAGG TGCAGGTGGA GTACAAGGGT GAGATGAAGA CCTTCTTCCC AGAGGAGATC AAGCCCAAGg TGCAGGTGGA GTACAAGGGT GAgATGAAGA CCTTCTTCCC AGAGGAGATC AAGCCCAAGG TGCAGGTGGA GTACAAGGGT GAgATGAAGA CCTTCTTCCC AGAGGAGATC AAgCCCAAGg TGCAGGTGGA GTACAAGgGT GAgAtGAAGA CCTTCTTCCC AgAgGAGATC AAGCCCAAGG TGCAGGTGGA GTACAAGgGT GAgATGAAGA CCTTCTTCCC AgAgGAGATC

$$
\ldots|\ldots|_{370} \ldots|\ldots|_{380} \ldots|\cdots|_{390} \ldots|\cdots|_{400} \ldots|\cdots|_{410} \ldots|\cdots|_{420}
$$

AGCTCTATGG TGCTCACCAA GATGAAGGAG ATTGCTGAGG CCTATCTGGG AAAAAAGGTA

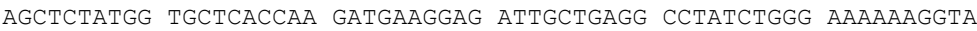
AgCTCTATGg TGCTCACCAA GATGAAgGA ATTGCTGAgG CCTATCTGGg AAAAAAgGTA

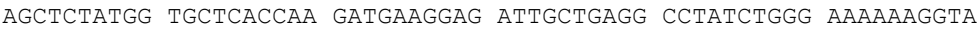
AgCtCtAtg tgCtCACCAA GAtgAAgGAg AttgCtgAgg CCTAtCtgGg AAAAAAgGtA

$$
\left.\left.\cdots|\cdots|\right|_{430} \ldots|\ldots|\right|_{440} \ldots|\cdots|_{450} \ldots|\cdots|_{460} \ldots \mid
$$

GAgACTGCTG TTATCACAGT GCCCGCTTAC TTCAACGACT CCCAG

CAgA

CAGA ATGCTG TTATCACAGT GCCCGCTTAC TTCAACGACT CCCAG

CAgA

CAgAATGCTG TTATCACAGT GCCCGCTTAC TTCAACGACT CCCAG

Figure 5. Alignment of four haplotypes in coding region of the HSP70 gene in Kampung Unggul Balitbangtan (KUB), Walik, and Kate Walik chickens with the chicken reference sequence. Bold: start codon; hyphens: nucleotide base deletions; in box: transition and transvertions.

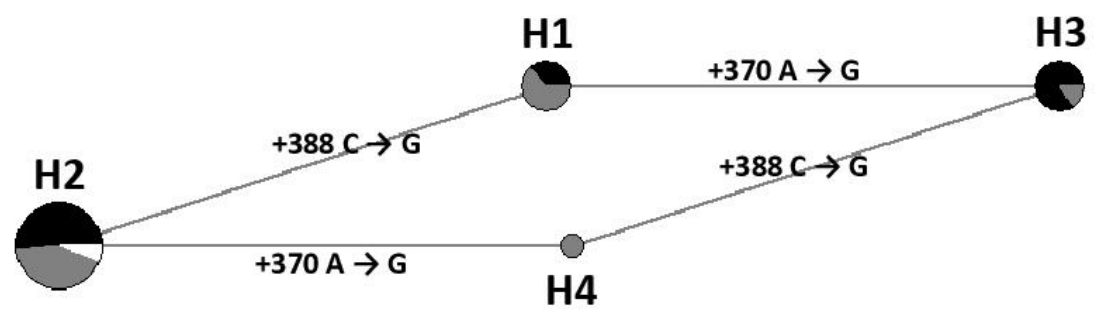

Figure 6. Median-Joining network HSP70 gene haplotypes in Kampung Unggul Balitbangtan (KUB, $\square)$, Walik ( $\square)$, and Kate Walik ( $\square$ ) chickens. Haplotype 1 (H1), haplotype $2(\mathrm{H} 2)$, haplotype $3(\mathrm{H} 3)$, and haplotype 4 (H4) are occurred based on mutations at positions g.370A $>\mathrm{G}$ and g.388C $>\mathrm{G}$. 


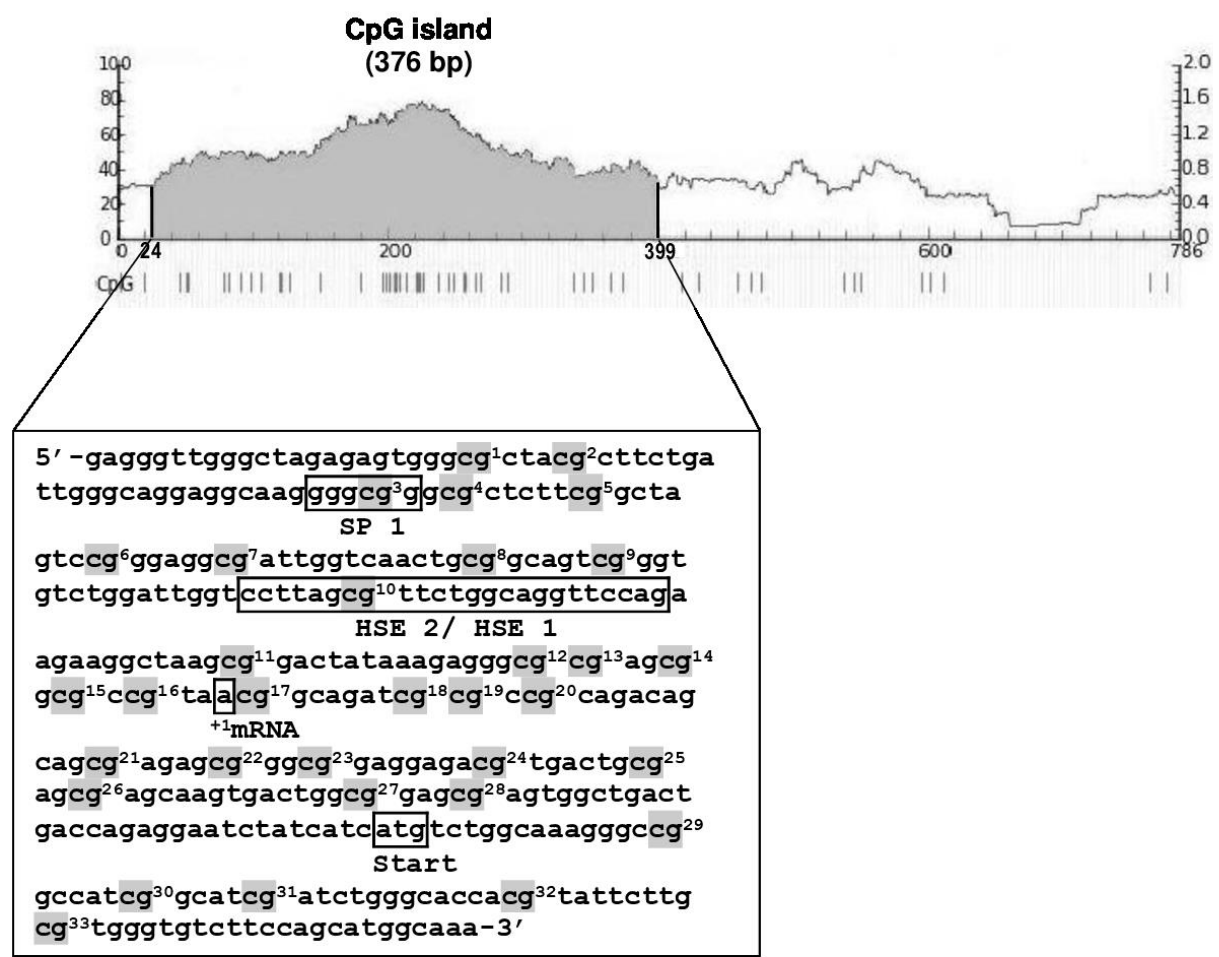

Figure 7. CpG island of HSP70 gene promoter and exon in Kampung Unggul Balitbangtan (KUB), Walik, and Kate Walik chickens

Table 5. Sequence base composition of HSP70 gene promoter and exon, and CpG island in Kampung Unggul Balitbangtan (KUB), Walik, and Kate Walik chickens

\begin{tabular}{|c|c|c|c|c|c|c|c|}
\hline \multirow{2}{*}{ Breed } & \multirow{2}{*}{$\begin{array}{l}\text { Sequence promoter } \\
\text { and exon (bp) }\end{array}$} & \multicolumn{6}{|c|}{ Base composition (\%) } \\
\hline & & $\mathrm{A}$ & $\mathrm{T}$ & G & $\mathrm{C}$ & $\mathrm{A}+\mathrm{T}$ & $\mathrm{G}+\mathrm{C}$ \\
\hline Ref. chicken & 787 & 23.8 & 18.2 & 32.7 & 25.3 & 42.0 & 58.0 \\
\hline \multicolumn{8}{|l|}{ KUB } \\
\hline Haplotype 1 & 786 & 23.8 & 18.2 & 32.7 & 25.3 & 42.0 & 58.0 \\
\hline Haplotype 2 & 786 & 23.8 & 18.2 & 32.8 & 25.2 & 42.0 & 58.0 \\
\hline Haplotype 3 & 786 & 23.7 & 18.2 & 32.8 & 25.3 & 41.9 & 58.1 \\
\hline \multicolumn{8}{|l|}{ Walik } \\
\hline Haplotype 1 & 786 & 23.8 & 18.2 & 32.7 & 25.3 & 42.0 & 58.0 \\
\hline Haplotype 2 & 786 & 23.8 & 18.2 & 32.8 & 25.2 & 42.0 & 58.0 \\
\hline Haplotype 3 & 786 & 23.7 & 18.2 & 32.8 & 25.3 & 41.9 & 58.1 \\
\hline Haplotype 4 & 786 & 23.7 & 18.2 & 32.9 & 25.2 & 41.9 & 58.1 \\
\hline \multicolumn{8}{|l|}{ Kate Walik } \\
\hline Haplotype 2 & 786 & 23.8 & 18.2 & 32.8 & 25.2 & 42.0 & 58.0 \\
\hline CpG island 1 & 376 & 20.5 & 17.8 & 38.6 & 23.1 & 38.3 & 61.7 \\
\hline
\end{tabular}

have potential to be used for marker-assisted selection (MAS) of reproductive traits in Pasundan cattle (Said \& Putra, 2018).

In most organisms, the HSP70 gene does not usually have introns, is quite conserved, and, in many avian species, the protein coding regions have the same length i.e., 1,905 bp (Morimoto et al., 1986; Mazzi et al., 2003; Xia et al., 2013; Zhang et al., 2015). The complete coding-region sequences of HSP70 gene are available at NCBI for a number of avian species, including chicken (G. gallus, with accession numbers of J02579, AY143691, AY143692, and AY143693), guinea fowl (Numida meleagris, with accession number of AB096696), Japanese quail (Coturnix japonica, with accession number of
AB259847), duck (Anas platyrhynchos, with accession number of EU678246), and goose (Anser cygnoides, with accession number EU680475). The coding region of avian HSP70 gene generally starts with the standard start codon of ATG, ends with the stop codon of TAA, and codes for 633 amino acids.

Based on our analysis of the protein coding region (465 bp) of HSP70 genes in KUB, Walik, and Kate Walik chickens, four haplotypes were detected (Table 4). Mazzi et al. (2003) show that three hsp70 alleles (hsp70-1, hsp70-2, and hsp70-3) are found based on the polymorphisms at positions g.370A $>\mathrm{G}$ (identical to g.258A $>\mathrm{G}$ ) and g.388C $>\mathrm{G}$ (identical to g.276C $>\mathrm{G}$ ) in the protein coding region of the HSP70 genes of broiler and naked neck 
chickens. We recognize that our $\mathrm{H} 1$ is $100 \%$ identical to the hsp70-3 allele in Pescoco Pelado 1 (with accession number of AY143692), H2 is 100\% similar to the hsp702 allele in Hubbard Pettersen (with accession number of AY143693), and H3 is $100 \%$ identical to the hsp70-1 allele in Pescoco Pelado 1 (with accession number of AY143691). We find a new haplotype, H4, that is only found in Walik chickens in this study.

The mutation that is occurred at position g.370A $>\mathrm{G}$ produces the amino acid serine, while the mutation at position $\mathrm{g} .388 \mathrm{C}>\mathrm{G}$ produces the amino acid proline. The two mutations have no changes to the original amino acid sequence of the HSP70 and are so-called silent mutations (Mazzi et al., 2003). The silent mutations occurred in the coding region of the chicken HSP70 gene have been used as molecular markers for determining heat resistance in chickens (Mazzi et al., 2003). Polymorphisms in the chicken HSP70 gene are detected by the PCR single-strand conformation polymorphism (PCR-SSCP) method (Tamzil et al., 2013a; Liang et al., 2016) and PCR restriction fragment length polymorphism (PCR-RFLP) analysis (Duangjinda et al., 2017). Research on the HSP70 gene using the PCR-SSCP method has succeeded in identifying seven genotypes in Kampung Lombok chickens ( $\mathrm{AA}, \mathrm{AB}, \mathrm{AC}, \mathrm{CC}, \mathrm{AD}, \mathrm{DD}$, and $\mathrm{BC}$ ), six genotypes in Arabian chickens (AA, AB, AC, CC, AD, and $\mathrm{BC}$ ), but only one genotype (DD) in commercial laying chickens (Tamzil et al., 2013a). Based on the associations observed between chicken breeds and HSP70 gene genotypes and heat stress, native chickens appear to have the best heat resistance, while the most highly heat-tolerant genotype is AD (Tamzil et al., 2013b). Liang et al. (2016) have shown the association between HSP70 gene polymorphisms detected by PCR-SSCP method with the acute temperature tolerance, growth, and egg production in Taiwanese local chickens. Only AA genotype (g.258A $>\mathrm{G}$ ) shows a high tolerance level to acute temperatures (at $40{ }^{\circ} \mathrm{C}$ for 1 hour), without affecting the growth performance and egg production (Liang et al., 2016). Thailand local and broiler chickens produce $\mathrm{C}$ and M loci, based on PCR-RFLP analysis with the restriction enzymes of CfrI and MmeI (New England Biolabs, Ipswich, MA) in coding region of the HSP70 gene, but only $\mathrm{C} 1 \mathrm{C} 1$ and $\mathrm{C} 1 \mathrm{C} 2$ genotypes that can be used as heat stress markers (Duangjinda et al., 2017).

CpG is shorthand for $5^{\prime}-\mathrm{C}-$ phosphate-G-3'. CpG islands are regions with high frequency of $\mathrm{CpG}$ sites. The usual formal definition of $\mathrm{CpG}$ islands is a region with at least $200 \mathrm{bp}$, a GC percentage of greater than $50 \%$, and observed-to-expected CpG ratio greater than $60 \%$ (Gardiner-Garden \& Frommer, 1987). Many genes have $\mathrm{CpG}$ islands associated with the start of the gene (promoter regions). Methylation of $\mathrm{CpG}$ sites in the promoter of a gene may inhibit gene expression. In vertebrate, $\mathrm{CpG}$ islands are typically occurred at or near the transcription start site of genes. A cytosine base (C) followed immediately by a guanine base $(G)$ is rare in vertebrate DNA, because the cytosines in such arrangement tend to be methylated. CpG islands are important because they represent areas of the genomes that have for some reasons been protected from mutating properties by methylation occurred through evolutionary time.
In our study, two of $33 \mathrm{CpG}$ sites are found in the consensus promoter element of chicken HSP70 gene: SP 1 and HSEs (Figure 7). Gan et al (2013) detect methylation levels of core promoter transcription sites (SP 1 and HSEs). The results indicate that there is no correlation between the DNA methylation of the transcription factor CpG and HSP70 expression.

\section{CONCLUSION}

Haplotype 4 is a novel haplotype that is only found in Walik chicken. The appearance of $\mathrm{H} 4$ is caused by the mutation received in two specific sites (g.370A $>\mathrm{G}$ and g.388C $>$ G). Walik chicken has a complete haplotype of HSP70 gene so that it can be used as a standard for heat stress genotyping in Indonesia local chickens.

\section{CONFLICT OF INTEREST}

We declare that there is no conflict of interest with any financial, personal, or other relationships with other people or organization related to the material discussed in the manuscript.

\section{ACKNOWLEDGEMENT}

The authors would like to thank and appreciate the Directorate General of Higher Education (DIKTI), The Ministry of Research, Technology, and Higher Education of The Republic of Indonesia for the financial support through BPPDN scholarship. We are grateful to Dr. Tike Sartika for permission to use KUB chickens.

\section{REFERENCES}

Araujo, P. R., K. Yoon, D. Ko, A. D. Smith, M. Qiao, U. Suresh, S. C. Burns, \&, L. O. F. Penalva. 2012. Before it gets started: regulating translation at the 5'UTR [review]. Comp. Funct. Genomics. 2012:475731. https://doi. org/10.1155/2012/475731

Archana, P. R., I. Aleena, P. Pragua, M. K. Vidya, A. P. A. Niyas, M. Bagath, G. Krishnan, A. Manimaran, V. Beena, E. K. Kurien, V. Sejian, \& R. Bhatta. 2017. Role of heat shock proteins in livestock adaptation to heat stress. J. Dairy Vet. Anim. Res. 5:00127. https://doi.org/10.15406/ jdvar2017.05.00127

Akerfelt, M., R. I. Morimoto, \& L. Sistonen. 2010. Heat shock factors: integrators of cell stress, development and lifespan. Nat. Rev. Mol. Cell Biol. 11:545-555. https://doi. org/10.1038/nrm2938

Carabańo, M.J., M. Ramŏn, A. Menéndez-Buxadera, A. Molina \& C. Diaz. 2019. Selecting for heat tolerance. Animal Font. 9:62-68. https://doi.org/10.1093/af/vfy033

Chen, Z. Y., W. W. Zhang, J. K. Gan, L. N. Kong, X. Q. Zhang, D. X. Zhang, \& Q. B. Luo. 2016. Genetic effect of an A/G polymorphism in the HSP70 gene on thermotolerance in chicken. Genet. Mol. Res. 15: gmr.15028271. https://doi. org/10.4238/gmr.15028271

Duangjinda, M., S. Tunim, C. Duangdaen, \& W. Boonkum. 2017. HSP70 genotypes and heat tolerance of commercial and native chickens reared in hot and humid conditions. Braz. J. Poultry Sci. 19:007-018. https://doi. org/10.1590/1806-9061-2016-0245.

Fathi, M.M., A. Galal, S. El-Safty, \& M. Mahrous. 2013. Naked neck and frizzle genes for improving chickens raised 
under high ambient temperature: I. Growth performance and egg production. World's Poult. Sci. J. 69:813-832. https://doi.org/10.1017/S0043933913000834

Fathi, M.M., A. Galal, S. El-Safty, \& M. Mahrous. 2014. Naked neck and frizzle genes for improving chickens raised under high ambient temperature: II. Blood parameters and immunity. World's Poult. Sci. J. 70:165-172. https://doi. org/10.1017/S0043933914000142

Fujimoto, M., \& A. Nakai. 2010. The heat shock factor family and adaptation to proteotoxic stress. FEBS J. 277:41124125. https://doi.org/10.111/j.1742-4658.2010.07827.x

Gan, J.K., D.X. Zhang, D.I. He, X.Q. Zhang, Z.Y. Chen, \& Q.B. Luo. 2013. Promoter methylation negatively correlated with mRNA expression but not tissue differential expression after heat stress. Genet. Mol. Res. 12:809-819. https:// dx.doi.org/10.4238/2013.MARCH.15.1

Gan, J. K., L. Y. Jiang, L. N. Kong, X. Q. Zhang, \& Q. B. Luo. 2015. Analysis of genetic diversity of the heat shock protein 70 gene on the basis of abundant sequence polymorphisms in chicken breeds. Genet. Mol. Res. 14:1538-1545. https://dx.doi.org/10.4238/2015.March.6.1

Gardiner-Garden, M., \& M. Frommer. 1987. CpG islands in vertebrate genomes. J. Mol. Biol. 196:261-282. https://doi. org/10.1016/0022-2836(87)90689-9

Hall, T. 2011. Bioedit: An important software for molecular biology. GERF Bull Biosciences. 2:60-61.

Leigh, J. W., \& D. Bryant. 2015. PopART: Full-feature software for haplotype network construction. Methods Ecol. Evol. 6:1110-1116. https://doi.org/10.1111/2041-210X.12410

Leppek, K., R. Das, \& M. Barna. 2018. Functional 5'UTR mRNA structures in eukaryotic translation regulation and how to find them. Nat. Rev. Mol. Cell. Biol. 19:158-174. https://doi. org/10.1038/nrm.2017.103

Liang, H. M., D. Y. Lin, Y. D. Hsuuw, T. P. Huang, H. L. Chang, C. Y. Lin, H. H. Wu, \& K. H. Hung. 2016. Association of heat shock protein 70 gene polymorphisms with acute thermal tolerance, growth, and egg production traits of native chickens in Taiwan. Arch. Anim. Breed. 59:173-181. https://doi.org/10.5194/aab-59-173-2016

Mazzi, C. M., J. A. Ferro, M. I. T. Ferro, V. J. M. Savino, A. A. D. Coelho, \& M. Macari. 2003. Polimorphism analysis of the hsp70 stress gene in broiler chickens (Gallus gallus) of different breeds. Gen. Mol. Biol. 26:275-281. https://doi. org/10.1590/S1415-47572003000300010

Mohamed, A. S. A., A. R. Lozovskiy, \& A. M. A. Ali. 2019. Strategies to combat the deleterious impacts of heat stress through feed restrictions and dietary supplementation (vitamins, minerals) in broilers. J. Indonesian Trop. Anim. Agric. 44:155-166. https://doi.org/10.14710/ jitaa.44.2.155-166

Morimoto, R. I., C. Hunt, S. Y. Huang, K. L. Berg, \& S. S. Benerji. 1986. Organization, nucleotide sequence, and transcription of the chicken HSP70 gene. J. Biol. Chem. 261:12692-12699.
Nataamijaya, A. G. 2010. Pengembangan potensi ayam lokal untuk menunjang peningkatan kesejahteraan petani. Jurnal Litbang Pertanian 29:131-138.

Ng, C. S., P. Wu, J. Foley, A. Foley, M-L. McDonald, W-T Juan, C-J Huang, Y-T. Lai, W-S. Lo, C-F. Chen, S. M. Leal, H. Zhang, R. B. Widelitz, P. I Patel, W-H Li, \& C-M. Chuong. 2012. The chicken frizzle feather is due to an $\alpha$-Keratin (KRT75) mutation that causes a defective rachis. PLoS Genet. 8:e1002748. https://doi.org/10.1371/journal. pgen.1002748

Pelham, H. R. B. 1982. A regulatory upstream promoter element in the Drosophila HSP70 heat-shock gene. Cell. 30:517-528. https://doi.org/10.1016/0092-8674(82)90249-5

Rayani, T. F., R. Mutia, \& Sumiati. 2017. Supplementation of zinc and vitamin $\mathrm{E}$ on apparent digestibility of nutrient, carcass traits, and mineral availability in broiler chickens. Med. Pet. 40:20-27. https://doi.org/10.5398/ medpet.2017.40.1.20

Said, S., \& W. P. B. Putra. 2018. Novel single nucleotide polymorphisms (SNPs) in the 5'UTR of bovine heat shock protein $70\left(\mathrm{bHSP}_{70}\right)$ gene and its association with service per conception $(\mathrm{S} / \mathrm{C})$ of pasundan cattle [short communication]. Biodiversitas 19:1622-1625. https://doi.org/10.13057/ biodiv/d190504

Sartika, T., S. Iskandar, \& B. Tiesnamurti. 2016. Sumberdaya Genetik Ayam Lokal Indonesia dan Prospek Pengembangannya. IAARD Press, Jakarta.

Tamura, K., G. Stecher, D. Peterson, A. Filipski, \& S. Kumar. 2013. MEGA6: Molecular evolutionary genetics analysis version 6. Mol. Biol. Evol. 30:2725-2729. https://doi. org $/ 10.1093 / \mathrm{molbev} / \mathrm{mst} 197$

Tamzil, M. H., R. R. Noor, P. S. Hardjosworo, W. Manalu, \& C. Sumantri. 2013a. Keragaman gen heat shock protein 70 pada ayam kampung, ayam arab dan ayam ras. J. Vet. 14:317-326.

Tamzil, M. H., R. R. Noor, P. S. Hardjosworo, W. Manalu, \& C. Sumantri. 2013b. Acute heat stress responses of three lines of chickens with different heat shock protein (HSP)70 genotypes. Int. J. Poult. Sci. 12:264-272.

Tamzil, M. H. 2014. Stres panas pada unggas: metabolisme, akibat dan upaya penanggulangannya. Wartazoa 24:57-66.

Tkáčová, J., \& M. Angelovičová. 2012. Heat shock protein (HSPs): a review. J. Anim. Sci. Biotechnol. 45:349-353.

Xia, M., J. Gan, Q. Luo, X. Zhang, \& G. Yang. 2013. Identification of duck HSP70 gene, polymorphism analysis and tissue expression under control and heat stress conditions. Br. Poult. Sci. 54:562-566. https://dx.doi.org/10.1080/00071668 .2013.819487

Zhang, W. W., X. Xiao, J. K. Gan, X. Q. Zhang, L. N. Kong, \& Q. B. Luo. 2015. Characterization of HSP70 and its expression in tissue: correlation with physiological and immune indices in goose (Anser cygnoides) serum. Genet. Mol. Res. 14:12288-12298. https://doi.org/10.4238/2015.October.9.17 